\title{
MENINGKATKAN KEMAMPUAN KOMUNIKASI MATEMATIS DAN KEPERCAYAAN DIRI SISWA SMP MENGGUNAKAN PENDEKATAN CONTEXTUAL TEACHING AND LEARNING
}

\author{
Seni Nuryanti ${ }^{1}$, Epul Saepudin ${ }^{2}$, Masta Hutajulu ${ }^{3}$, Heris Hendriana ${ }^{4}$ \\ 1,2,3,4 IKIP SILIWANGI, Bandung \\ seninuryanti99@gmail.com
}

Penerimaan : 19 Juli 2019

Diterima: 15 Juni 2019

\begin{abstract}
ABSTRAK
Penelitian ini bertujuan untuk mengetahui peningkatan kemampuan komunikasi matematis dan kepercayaan diri siswa SMP dengan pendekatan contextual teaching and learning. Subjek yang digunakan dalam penelitian ini adalah seluruh siswa kelas VIII di SMP 1 Padalarang dan sebagai sampel di pilih dua kelas yaitu kelas eksperimen dan kelas kontrol pada semester genap tahun ajaran 2017-2018. Kesimpulan dari penelitian ini adalah kemampuan komunikasi matematis siswa dan kepercayaan diri kelas eksperimen lebih baik dibandingkan dengan siswa kelas kontrol.
\end{abstract}

Kata Kunci : kemampuan komunikasi matematis, kepercayaan diri, contextual teaching and learning

\begin{abstract}
This study aims to determine the improvement of mathematicial communication skills and self confidence of junior high school students with contextual teaching and learning approach. Subjects used in this study were all students of class VIII in SMP 1 Padalarang and as a sample selected two classes to be used as control class and experiment class in second semester of academic year 2017-2018. The conclusion of this research is students' mathematical communication skills and self confidence of experimental class is better than the control class students.
\end{abstract}

Keywords : mathematicial communication skills, self confidence, contextual teaching and learning

\section{PENDAHULUAN}

Dalam dunia pendidikan terdapat dua jenis pendidikan yaitu formal dan informal. Dalam pendidikan formal terdapat bermacam-macam mata pelajaran yang harus dipelajari oleh siswa salah satunya pelajaran Matematika. Mata pelajaran matematika merupakan suatu bidang studi yang selalu diajarkan dari jenjang sekolah dasar, sekolah menengah hingga sampai jenjang perguruan tinggi. Dari pernyataan tersebut terlihat betapa pentingnya mempelajari matematika untuk mencaoai tujuan pendidikan. Senada dengan pendapat Hendriana, dkk (2013) visi yang dimaksud adalah mengembangkan penguasaan konsep matematika serta penerapannya, serta memberi peluang berkembangnya kemampuan menalar yang logis, sistematik, kritis dan cermat, kreatif, menumbuhkan rasa 
percaya diri, dan rasa keindahan terhadap keteraturan sifat matematika, serta mengembangkan sikap obyektif dan terbuka yang sangat diperlukan dalam menghadapi masa depan yang selalu berubah.

Pendidikan matematika sangat erat hubunganya dengan kehidupan sehari-hari maka dari itu, untuk meningkatkan pengetahuan siswa pada pelajaran matematika siswa diajak untuk mengenal dan menyelesaikan masalah matematika yang berkaitan dengan kenyataan yang dialami. Senada dengan pendapat Hutajulu \& Lexbin (2016) masalah-masalah kontekstual akan mempermudah siswa dalam mengkonstruksi pengetahuannya.

Menurut Yuliani (2015) salah satu yang menjadi focus utama pengembangan pembelajaran matematika dari sekolah dasar sampai dengan tingkat perguruan tinggi adalah kemampuan komunikasi matematisk. Dapat disimpulkan bahwa kemampuan komunikasi matematis dapat memberikan dampak positif kemajuan bagi pendidikan khususnya matematika dari tingkat dasar hingga perguruan tinggi. Oleh karena itu, mahasiswa program studi pendidikan matematika dan matematika diharapkan dapat mengkonstruksi dan menemukan definisi/konsep matematika secara mandiri, membuktikan secara logis, serta dapat mengembangkan kemampuan matematikanya secara lebih jauh (Hutajulu \& Minarti, 2017). Untuk merealisasikan tujuan pendidikan matematika, kemampuan komunikasi matematis siswa harus dikembangkan sejak dini hingga perguruan tinggi.

Namun sangat disayangkan pada kenyataannya masih banyak siswa yang merasa kesulitan dan kurang bersemangat dalam mempelajari matematika. Hal tersebut terlihat dari hasil penelitian yang dilakukan masih banyak siswa SMP Negeri 1 Padalarang khususnya kelas VIII yang merasa kesulitan untuk mengerjakan soal-soal matematika. Hal tersebut terlihat dari hasil ulangan sehari-hari siswa pada pelajaran matematika masih banyak siswa yang mendapatkan nilai kurang dari KKM, dan hasil wawancara dengan salah seorang guru matematika kelas VIII Ibu Ida menyatakan bahwa anak-anak banyak merasa kesulitan dan kurang bersemangat jika ada tugas atau pelajaran matematika dan kurang dalam memahami konsep matematika serta merasa kesulitan dalam proses perhitungan. Selain itu dari hasil wawancara peneliti dengan beberapa siswa kelas VIII secara random salah satunya bernama daffa, dia merasa kesulitan mempelajari matematika khususnya pada materi SPLDV dengan alasan terlalu banyak rumus. 
Hendriana, dkk (2017) merinci indikator komunikasi matematis ke dalam beberapa kegiatan matematis, antara lain: a) Menyatakan benda-benda nyata, situasi, dan peristiwa sehari-hari ke dalam bentuk model matematika (gambar, tabel, diagram, grafik, ekpresi aljabar; b) Menjelaskan ide, dan model matematika gambar, tabel, diagram, grafik, ekspresi aljabar) ke dalam bahasa biasa; c) Menjelaskan dan membuat pertanyaan matematika yang di pelajari; d) Mendengarkan, berdiskusi, dan menulis tentang matematika; e) Membaca dengan pemahaman suatu presentasi tertulis; dan f) Membuat konjektur, menyusun argumen, merumuskan definisi dan generalisasi. Indikator butir a) sama dengan butir c) merupakan pedoman dalam menyusun suatu tes matematika tertulis. Sedangkan semua indikator di atas digunakan untuk mengembangkan kemampuan komunikasi matematis selama dalam pembelajaran.

Kepercayaan diri sangat diperlukan dalam kehidupan terutama dalam dunia pendidikan khususnya matematika, dalam pembelajaran matematika siswa yang memiliki kepercayaan diri maka dia akan berusaha mencari tahu menggali pengetahuan dengan bertanya, dam semangat dalam memberikan argumen untuk menambah wawasan pengetahuan matematika. Menurut Hendriana (2014) walaupun ada orang yang mempunyai pemahaman lengkap dan kemampuan penuh di bidang apa yang sedang dilakukannya, kalau ia kurang mempunyai kepercayaan diri, ia akan jarang berhasil dalam tugasnya karena kemampuannya untuk memobilisasikan motivasi dan semua sumber daya yang dipunyainya (kepandaian, menggerakkan rekan kerja untuk membantu) menjadi tidak maksimal. Mengingat akan pentingnya kepercayaan diri siswa maka dibutuhkan pendekatan pembelajaran yang dapat menumbuhkan kepercayaan diri siswa yaitu kemampuan komunikasi matematis.।

Salah satu pendekatan pembelajaran yang sesuai dengan tujuan untuk mencapai kepercayaan diri yaitu pendekatan contextual teaching and learning. Sesuai dengan pendapat Yuliani (2015) pendekatan kontekstual memberikan arahan materi berdasarkan konteks-konteks yang ada dilingkungan sehari-hari yang sudah tidak asing bagi siswa, dengan demikian diharapkan siswa akan merasa senang untuk belajar matematika.

a. Dalam mencapai tujuan pendidikan matematika kemampuan komunikasi matematis dan kepercayaan diri siswa sangat dibutuhkan maka dari itu peneliti tertarik untuk menganalisis peningkatan siswa dalam kemampuan komunikasi matematis dengan pendekatan contextual teaching and learning. Dan seberapa besar dampak positif 
terhadap kepercayaan diri siswa yang menggunakan pendekatan contextual teaching and learning.

\section{METODOLOGI PENELITIAN}

Metode penelitian yang digunakan dallam penelitian ini adalah penelitian kuasi eksperimen. Tujuan penelitian ini adalah sama yaitu untuk menentukan sebab dan akibat serta adanya manipulasi langsung pada kondisi yang diinginkan, sedangkan yang membedakannya adalah dalam kuasi eksperimen tidak ada sistem acak atau random pada subjeknya Hendriana \& Afrilianto (2017: 14). Penelitian ini dilakukan pada subjek yang terbagi dua kelompok sampel yaitu kelas eksperimen dan kelas kontrol.

Telah dijelaskan bahwa pengambilan sampel ini tidak dilakukan secara acak, pengambilan sampel dilakukan dari hasil diskusi dengan pihak sekolah SMP 1 Padalarang tahun ajaran 2017-2018. Dengan memberikan dua kelas sebagai penelitian, lalu oleh peneliti dua kelas tersebut di bagi menjadi kelompok eksperimen dan kontrol.

Desain penelitiannya adalah pembagian sampel secara acak antara dua kelas yang diberikan dengan tindakan pembelajaran yang berbeda antara eksperimen yaitu menggunakan pendekatan contextual teaching and learning sedangkan kelas kontrolmenggunakan pendekatan saintifik. Meski tindakan yang berbeda tetapi kedua kelas diberikan pretest dan posttest yang sama, yaitu instrument tes kemampuan komunikasi matematis dan pengisian angket kepecayaan diri siswa.

Setelah dilakukan pretest pada dua kelompok tersebut dan diketahui hasilnya, lalu dilakukan tindakan yang berbeda pada kelompok kelas eksperimen dan kontrol. Setelah memberikan perlakuan yang berbeda pada kelas eksperimen dan kontrol lalu dilanjutkan dengan memberikan posttest yang terdiri dari tes kognitif dan tes afektif dengan menggunakan angket pada kelas eksperimen dan kontrol

Penelitian ini dilakukan di SMP Negeri 1 Padalarang kelas VIII pada semester genap tahun ajaran 2017/2018 dengan materi sistem persamaan linear dua variabel. Subjek dalam penelitian ini dikelompokkan pada dua kelompok yaitu kelas VIII C sebagai kelas eksperimen dan kelas VIII A sebagai kelas kontrol. 
Instrumen dalam penelitian ini terdiri dari dua jenis, yaitu tes kemampuan komunikasi matematis seperangkat soal tes yang berbentuk uraian yang terdiri dari 7 soal dan seperangkat tes kepercayaan diri siswa berbentuk angket terdiri dari 34 pernyataan. Instrumen di susun sendiri oleh peneliti dan angket dibuat berdasarkan sumber yang telah ada Hendriana dkk (2017), dengan sedikit modifikasi oleh peneliti.

Tes kemampuan komunikasi matematis yang berbentuk uraian diberikan untuk mengetahui kemampuan komunikasi matematis siswa, sedangkan tes kepercayaan diri siswa yang berbentuk angket yang digunakan dalam penelitian ini tujuannya untuk mengetahui kepercayaan diri siswa dalam pembelajaran.

Data dalam penelitian ini dikumpulkan berdasarkan hasil tes dan angket. Data yang berkaitan dengan kemampuan komunikasi matematis siswa dikumpulkan dengan melakukan tes. Sedangkan data yang berkaitan dengan kepercayaan diri siswa dikumpulkan dengan menggunakan angket.

Data yang akan dianaliusis adalah data kuantitatif berupa hasil tes kemampuan komunikasi matematis siswa dan data kualitatif berupa angket kepercayaan diri siswa. Seluruh data hasil penelitian diolah dengan menggunakan software SPSS 22.

\section{HASIL DAN PEMBAHASAN}

Data kuantitatif didapatkan dari tes kemampuan komunukasi matematis siswa di awal pembelajaran dan di akhir pembelajaran, serta pengisian angket self confidence terhadap 76 siswa, yang terdiri dari 38 siswa kelompok eksperimen dan 38 siswa kelompok kontrol.

Dalam penelitian ini diperoleh skor pretest, posttest dan N-Gain berdasarkan aspek kemampuan komunikasi matematis siswa dan kepercayaan diri siswa. Skor pretest digunakan untuk mengetahui kemampuan awal siswa sebelum diberikan perlakuan, skor posttest digunakan untuk mengetahui kemampuan akhir siswa setelah diberikan perlakuan. Berikut hasil skor pretest, posttest dan $N$-Gain untuk kelompok eksperimen dan kelompok kontrol: 
Tabel 1. Deskripsi Data Kelas Eksperimen dan Kelas Kontrol

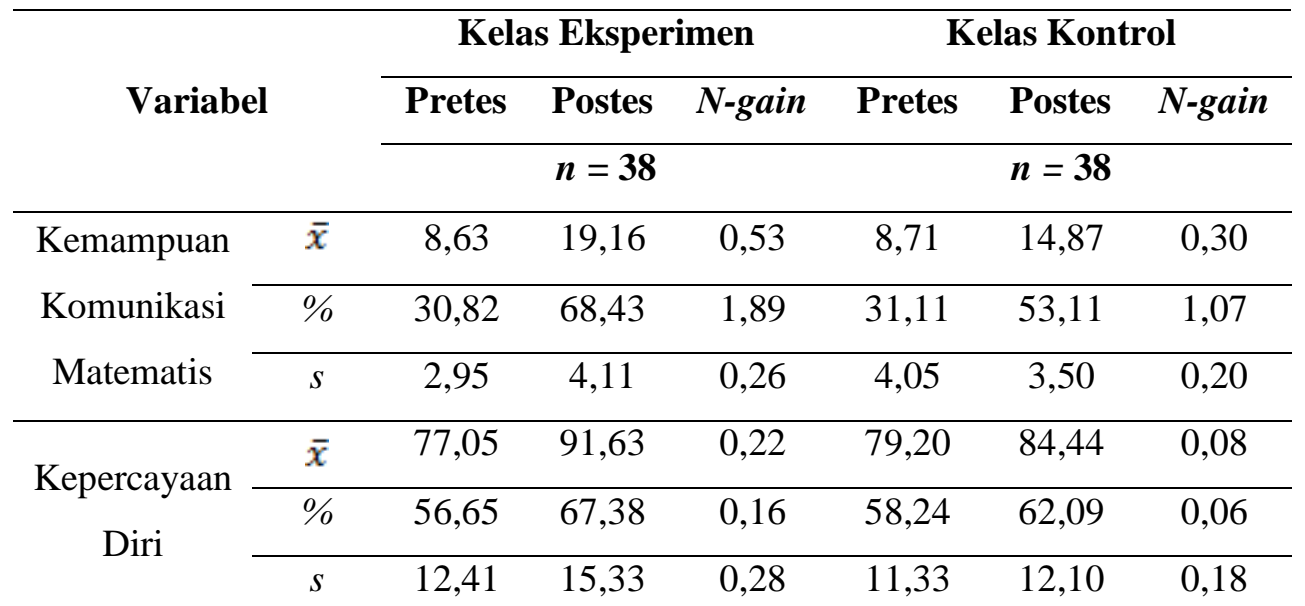

Catatan: $\quad$ Skor Maksimum Ideal tes Kemampuan Komunikasi Matematis $=28$ Skor Maksimum Ideal tes Kepercayaam Diri = 136

Berdasarkan Tabel 1 untuk kemampuan komunikasi matematis diperoleh ratarata pretes untuk kelas eksperimen yaitu 8,63 dengan persentase 30,82\% sedangkan untuk kelas kontrol yaitu 8,71 dengan persentase $31,11 \%$ maka selisih rata-rata nilai kelas eksperimen dan kelas kontrol adalah 0,08 atau 0,29\% tidak menunjukkan perbedaan yang jauh. Untuk skala sikap kepercayaan diri diperoleh rata-rata pretes untuk kelas eksperimen yaitu 77,05 dengan persentase 56,65\% sedangkan untuk kelas kontrol yaitu 79,20 dengan persentase 58,24\% maka selisih rata-rata nilai kelas eksperimen dan kelas kontrol adalah 2,15 atau 1,59\%. Terlihat bahwa selisih nilai ratarata kedua kelas tersebut tidak menunjukkan perbedaan yang jauh, maka secara deskriptif dapat disimpulkan bahwa rata-rata untuk kemampuan komunikasi matematis dan kepercayaan diri siswa awal kedua kelas sama. Dari Tabel 1 diperoleh simpangan baku kemampuan komunikasi matematis untuk kelas eksperimen adalah sebesar 2,95 dan kelas kontrol sebesar 4,05 yang artinya kemampuan awal dari komunikasi matematis pada kelas kontrol lebih menyebar atau lebih bervariasi dibandingkan kelas eksperimen. Dan simpangan baku kepercayaan diri untuk kelas eksperimen adalah sebesar 12,41 dan kelas kontrol sebesar 11,33 yang artinya skala sikap kepercayaan diri awal pada kelas eksperimen lebih menyebar atau lebih bervariasi dibandingkan kelas kontrol. 
Kemudian kemampuan komunikasi matematis diperoleh rata-rata posttest untuk kelas eksperimen sebesar 19,16 dengan persentase 68,43\%, sedangkan skor rata-rata hasil posttest kelas kontrol adalah 14,87 dengan persentase 53,11\%. Dan untuk skala sikap kepercayaan diri skor rata-rata hasil postes kelas eksperimen sebesar 91,63 dengan persentase $67,38 \%$, sedangkan skor rata-rata hasil postes kelas kontrol adalah 84,44 dengan persentase $62,09 \%$. Dari hasil tersebut secara deskriptif dapat disimpulkan bahwa skor rata-rata kelas eksperimen pada kemampuan komunikasi matematis dan sikap kepercayaan diri lebih baik daripada kelas kontrol serta persentasenya lebih besar dibandingkan kelas kontrol. Kemudian untuk simpangan baku postes kemampuan komunikasi matematis kelas eksperimen sebesar 4,11 dan kelas kontrol adalah 3,50 lalu pada skala sikap simpangan baku postes kelas eksperimen sebesar 15,33 dan simpangan baku untuk postes kelas kontrol adalah 12,10 yang berarti bahwa kemampuan komunikasi matematis dan kepercayaan diri siswa pada kelas eksperimen lebih menyebar atau lebih bervariasi dibandingkan kelas kontrol. Selanjutnya dari Tabel 1 terlihat bahwa rata-rata $N$-gain kemampuan komunikasi matematis dari kelas eksperimen yaitu 0.53, sedangkan untuk kelas kontrol yaitu 0,30 . Terlihat bahwa rata-rata $N$-gain kelas eksperimen lebih besar daripada kelas kontrol, sehingga dapat disimpulkan seacara deskriptif bahwa kelas eksperimen memiliki peningkatan kemampuan komunikasi matematis yang lebih baik dibandingkan kelas kontrol. Kemudian $N$-gain kepercayaan diri kelas eksperimen yaitu 0,22 , sedangkan untuk kelas kontrol yaitu 0,08. Dari data tersebut terlihat bahwa rata-rata $\mathrm{N}$-gain kelas eksperimen lebih besar daripada kelas kontrol, sehingga dapat disimpulkan seacara deskriptif bahwa kelas eksperimen memiliki peningkatan skala sikap kepercayaan diri yang lebih baik dibandingkan kelas kontrol.

\section{Analisis Skor Pretest Kemampuan Komunikasi Matematis dan Kepercayaan Diri}

Uji normalitas data pretes dilakukan untuk mengetahui normal tidaknya distribusi nilai pretes. Uji normalitas ini menggunakan uji Kolmogorov-smirnov dengan taraf signifikansi 0,05 karena data yang digunakan dalam penelitian ini berskala ordinal dengan subjek penelitian $\geq 30$ (Ruseffendi, 2012) yang berguna untuk menguji apakah suatu sampel berasal dari suatu populasi dengan distribusi tertentu, terutama distribusi normal. Adapun pengujian hipotesis uji normalitas dalam penelitian ini adalah sebagai berikut: 
Tabel 2 Uji Normalitas Kemampuan Komunikasi Matematis dan Kepercayaan Diri

\begin{tabular}{ccccccc}
\hline \multirow{2}{*}{ Kelas } & \multicolumn{3}{c}{ Koneksi } & \multicolumn{3}{c}{ Motivasi Belajar } \\
\cline { 2 - 7 } & \multicolumn{2}{c}{ Kolmogorov-Smirnov } & \multicolumn{2}{c}{ Kolmogorov-Smirnov } \\
\cline { 2 - 7 } & Statistic & Df & Sig & Statistic & Df & Sig \\
\hline Eksperimen & 0,243 & 38 & 0,000 & 0,193 & 38 & 0,001 \\
\hline Kontrol & 0,096 & 38 & 0,200 & 0,173 & 38 & 0,006 \\
\hline
\end{tabular}

Dari tabel 2 terlihat bahwa pada kemampuan komunikasi matematis siswa diperoleh nilai signifikansi kelas eksperimen sebesar 0,000 dan kelas kontrol sebesar 0,200. Karena nilai signifikansi salah satu kelas yaitu kelas eksperimen kurang dari 0,05 atau kurang dari $5 \%$, maka $\mathrm{H}_{0}$ ditolak yang berarti sampel kedua kelas tidak berdistribusi normal. Sedangkan pada kepercayaan diri diperoleh nilai signifikansi kelas eksperimen sebesar 0,001 dan kelas kontrol sebesar 0,006. Karena nilai signifikansi kedua kelas kurang dari 0,006 atau kurang dari 5\%, maka $\mathrm{H}_{0}$ ditolak yang berarti sampel kedua kelas tidak berdistribusi normal. Karena kedua kelas tidak berdistribusi normal, maka tidak akan dilakukan uji homogenitas varians melainkan akan dilanjutkan dengan uji non-parametrik Mann-Whitney untuk melihat perbedaan kemampuan awal komunikasi matematis dan kepercayaan diri kelas eksperimen dan kelas kontrol.

Tabel 3. Uji Kesamaan Rerata Komunikasi Matematis dan Kepercayaan Diri

\begin{tabular}{lcc}
\hline & $\begin{array}{c}\text { Nilai Komunikasi } \\
\text { Matematis }\end{array}$ & $\begin{array}{c}\text { Nilai Kepercayaan } \\
\text { Diri }\end{array}$ \\
\hline Mann-Whitney $U$ & 721.500 & 631,000 \\
\hline Wilcoxson $W$ & 1.462 .500 & 1372,000 \\
\hline$Z$ & $-0,005$ & $-0,945$ \\
\hline $\begin{array}{l}\text { Asymp.Sig.(2- } \\
\text { tailed) }\end{array}$ & 0,996 & 0,344 \\
\hline
\end{tabular}

Pada tabel 3 menunjukkan hasil perhitungan Mann-Whitney pada kedua kelas menunjukkan kemampuan komunikasi matematis nilai signifikansinya 0,996 dan nilai pada kepercayaan diri signifikansinya 0,344 . Nilai tersebut memenuhi kriteria pengujian yaitu nilai sig > 0,05 maka $\mathrm{H}_{0}$ diterima. Hal ini menunjukan tidak terdapat perbedaan yang signifikan antara kemampuan awal pada kemampuan koneksi matematik siswa di kelas eksperimen maupun siswa di kelas kontrol. 


\section{Analisis Skor Posttest Kemampuan Komunikasi Matematis dan Kepercayaan Diri}

Untuk mengetahui apakah kemampuan komunikasi matematis dan kepercayaan diri siswa yang mengikuti pembelajaran contextual teaching and learning lebih baik daripada yang mengikuti pembelajaran saintifik, maka dilakukan uji normalitas data terlebih dahulu dilanjutkan dengan uji perbedaan rata-rata.

\section{Tabel 4. Uji Normalitas Posttest Kemampuan Komunikasi Matematis dan Kepercayaan Diri}

\begin{tabular}{ccccccc}
\hline \multirow{2}{*}{ Kelas } & \multicolumn{3}{c}{ Koneksi } & \multicolumn{3}{c}{ Motivasi Belajar } \\
\cline { 2 - 7 } & \multicolumn{2}{c}{ Kolmogorov-Smirnov } & \multicolumn{2}{c}{ Kolmogorov-Smirnov } \\
\cline { 2 - 7 } & Statistic & Df & Sig & Statistic & Df & Sig \\
\hline Eksperimen & 0,200 & 38 & 0,001 & 0,202 & 38 & 0,000 \\
\hline Kontrol & 0,206 & 38 & 0,000 & 0,113 & 38 & 0,200 \\
\hline
\end{tabular}

Dari tabel 4 terlihat bahwa pada kemampuan komunikasi matematis siswa diperoleh nilai signifikansi kelas eksperimen sebesar 0,001 dan kelas kontrol sebesar 0,000. Karena nilai signifikansi kedua kelas kurang dari 0,005 atau kurang dari 5\%, maka $\mathrm{H}_{0}$ ditolak yang berarti sampel kedua kelas tidak berdistribusi normal. Sedangkan pada kepercayaan diri diperoleh nilai signifikansi kelas eksperimen sebesar 0,000 dan kelas kontrol sebesar 0,200. Karena nilai signifikansi salah satu kelas yaitu kelas kontrol kurang dari 0,005 atau kurang dari 5\%, maka $\mathrm{H}_{0}$ ditolak yang berarti sampel kedua kelas tidak berdistribusi normal. Karena kedua kelas tidak berdistribusi normal, maka tidak akan dilakukan uji homogenitas varians melainkan akan dilanjutkan dengan uji non-parametrik Mann-Whitney untuk melihat perbedaan kemampuan komunikasi matematis dan kepercayaan diri kelas eksperimen dan kelas kontrol.

\section{Tabel 5. Data Hasil Uji Perbedaan Rataan Skor Posttest Kemampuan Komunikasi Matematis}

\begin{tabular}{lcc}
\hline & $\begin{array}{c}\text { Nilai Komunikasi } \\
\text { Matematis }\end{array}$ & $\begin{array}{c}\text { Nilai Kepercayaan } \\
\text { Diri }\end{array}$ \\
\hline Mann-Whitney $U$ & 289,500 & 450,000 \\
\hline Wilcoxson $W$ & $1,030,500$ & 1191,000 \\
\hline$Z$ & $-4,525$ & $-2,827$ \\
\hline $\begin{array}{l}\text { Monte Carlo Sig. } \\
\text { (1-tailed) }\end{array}$ & 0,000 & 0,002 \\
\hline
\end{tabular}


Pada tabel 5 diperoleh nilai signifikansi Monte Carlo Sig. (1-tailed) 0,000 atau < 0,05 maka $\mathrm{H}_{0}$ ditolak artinya pencapaian kemampuan komunikasi matematis siswa SMP yang pembelajarannya menggunakan pendekatan contextual teaching and learning lebih baik daripada yang menggunakan pembelajaran biasa. Berdasarkan data pada Tabel 5 diperoleh nilai signifikansi Monte Carlo Sig. (1-tailed) 0,002 atau < 0,05 maka $\mathrm{H}_{0}$ ditolak artinya pencapaian kemampuan kepercayaan diri siswa SMP yang pembelajarannya menggunakan pendekatan contextual teaching and learning lebih baik daripada yang menggunakan pembelajaran biasa.

\section{Tabel 6. Hasil Uji Normalitas Data N-gain Kemampuan Komunikasi Matematis}

\begin{tabular}{cccc}
\hline \multirow{2}{*}{ Kelas } & \multicolumn{3}{c}{ Kolmogorov-Smirnov } \\
\cline { 2 - 4 } & Statistic & df & Sig. \\
\hline Eksperimen & 0,180 & 38 & 0,003 \\
\hline Kontrol & 0,122 & 38 & 0,164 \\
\hline
\end{tabular}

Dari tabel 6 diperoleh nilai signifikansi kelas eksperimen sebesar 0,003 dan kelas kontrol sebesar 0,164. Karena nilai signifikansi salah satu kelas yaitu kelas eksperimen kurang dari 0,05 atau kurang dari 5\%, maka $\mathrm{H}_{0}$ ditolak yang berarti sampel kedua kelas tidak berdistribusi normal. Karena kedua kelas tidak berdistribusi normal, maka tidak akan dilakukan uji homogenitas varians melainkan akan dilanjutkan dengan uji non-parametrik Mann-Whitney.

\section{Tabel 7. Data Uji Perbedaan Dua Rata-rata Data $N$-gain Kemampuan Komunikasi Matematis}

\begin{tabular}{crr}
\hline Mann-Whitney $U$ & $\mathbf{2 6 3 , 0 0 0}$ & Ho $_{0}$ ditolak \\
\cline { 1 - 2 } Monte Carlo Sig. (1-tailed) & 0,000
\end{tabular}

Berdasarkan data pada Tabel 7 diperoleh nilai signifikansi Monte Carlo Sig. (1tailed) 0,000 atau $<0,05$ maka $\mathrm{H}_{0}$ ditolak artinya peningkatan kemampuan komunikasi matematis siswa SMP yang pembelajarannya menggunakan pendekatan contextual teaching and learning lebih baik daripada yang menggunakan pembelajaran biasa. 
Tabel 8. Hasil Uji Normalitas Data $N$-gain Kepercayaan Diri

\begin{tabular}{cccc}
\hline \multirow{2}{*}{ Kelas } & \multicolumn{3}{c}{ Kolmogorov-Smirnov } \\
\cline { 2 - 4 } & Statistic & Df & Sig. \\
\hline Eksperimen & 0,120 & 38 & 0,184 \\
\hline Kontrol & 0,107 & 38 & 0,200 \\
\hline
\end{tabular}

Berdasarkan Tabel 8 di atas, diperoleh nilai signifikansi kelas eksperimen sebesar 0,184 dan kelas kontrol sebesar 0,200. Karena nilai signifikansi kedua kelas lebih dari 0,05 atau lebih dari $5 \%$, maka $\mathrm{H}_{0}$ diterima yang berarti sampel kedua kelas berdistribusi normal. Karena kedua kelas berdistribusi normal, maka selanjutnya akan dilakukan uji homogenitas varians untuk melihat apakah kedua antara kelas eksperimen dan kelas kontrol memiliki varians yang sama atau tidak.

Tabel 9. Hasil Uji Homogenitas Data $N$-gain Kepercayaan Diri

\begin{tabular}{cccc}
\hline Levene Statistic & df1 & df2 & Sig. \\
\hline $\mathbf{4 , 2 7 5}$ & 1 & 74 & 0,042 \\
\hline
\end{tabular}

Berdasarkan Tabel 9 di atas, diperoleh nilai signifikansinya adalah 0,042 dimana nilai signifikansi tersebut $<0,05$. Sesuai dengan kriteria pengujian maka untuk kedua kelas tidak memiliki varians yang homogen. Maka langkah selanjutnya adalah uji perbedaan rata-rata $\left(\mathrm{Uji}-t^{\prime}\right)$.

\section{Tabel 10. Hasil Uji Perbedaan Rata-rata Data $N$-gain Kepercayaan Diri}

\begin{tabular}{cccc}
\hline $\begin{array}{c}\text { Self_Confidence } \\
\text { Equal variances not assumed }\end{array}$ & $\mathbf{t}$ & Df & $\begin{array}{c}\text { Sig. (2- } \\
\text { tailed) }\end{array}$ \\
\cline { 2 - 4 } & 2,618 & 64,494 & 0,011 \\
\hline
\end{tabular}

Berdasarkan Tabel 10 di atas, diperoleh nilai Sig.(2-tailed $)=0,011$, dimana nilai tersebut $<0,05$. Sesuai dengan kriteria yang digunakan dalam pengujian ini, maka $\mathrm{H}_{0}$ ditolak yang artinya peningkatan kemampuan kepercayaan diri siswa SMP yang pembelajarannya menggunakan pendekatan contextual teaching and learning lebih baik daripada yang menggunakan pembelajaran biasa. 


\section{KESIMPULAN}

Berdasarkan hasil penelitian dapat diambil kesimpulan sebagai berikut:

1. Pencapaian kemampuan komunikasi matematis siswa yang pembelajarannya menggunakan pendekatan contextual teaching and learning lebih baik daripada yang menggunakan pembelajaran biasa.

2. Peningkatan kemampuan komunikasi matematis siswa yang pembelajarannya menggunakan pendekatan contextual teaching and learning lebih baik daripada yang menggunakan pembelajaran biasa.

3. Pencapaian kepercayaan diri siswa yang pembelajarannya menggunakan pendekatan contextual teaching and learning lebih baik daripada yang menggunakan pembelajaran biasa.

4. Peningkatan kepercayaan diri siswa yang pembelajarannya menggunakan pendekatan contextual teaching and learning lebih baik daripada yang menggunakan pembelajaran biasa.

\section{REFERENSI}

Hendriana, H., Sumarmo, U., \& Rohaeti, E. E. (2013). Kemampuan Komunikasi Matematik serta Kemampuan dan Disposisi Berpikir Kritis Matematik. Jurnal Matematika Dan Pendidikan Matematika, 2(1), 35-45.

Hendriana, H. (2014). Membangun Kepercayaan Diri Siswa Melalui Pembelajaran Matematika Humanis. Jurnal Pengajaran MIPA, 19(1), 52-60.

Hendriana, H \& Afrilianto, M. (2017). Langkah Praktis Penelitian Tindakan Kelas Bagi Guru. Bandung: PT. Refika Aditama.

Hendriana, dkk. (2017). Hard Skills dan Soft Skils Matematik Siswa. Bandung: Refika Aditama.

Hutajulu, M. \& Lexbin, M. (2016). Analisis Penerapan Pembelajaran Matematika Berbasis PMRI pada Sekolah Dasar di Kota Bandung. Jurnal Ilmiah UPT P2M STKIP Siliwangi. 3(1).

Hutajulu, M., \& Minarti, E. D. (2017). Meningkatkan Kemampuan Advanced Mathematical Thinking dan Habits Of Mind Mahasiswa Melalui Pendekatan Keterampilan Metakognitif. JES-MAT, 3(2).

Yuliani, A. (2015). Meningkatkan Kemampuan Komunikasi Matematik pada Mahasiswa melalui Pendekatan Contextual Teaching Learning (CTL). Infinity Journal, 4(1), 19. 